\title{
Literacies in contact when writing Wolof - orthographic repertoires in digital
}

\section{communication}

Kristin Vold Lexander, MultiLing Center for Multilingualism in Society Across the Lifespan, University of Oslo

\section{Abstract}

This paper investigates the resources writers activate when they spell Wolof, a West African language they usually use more in spoken than in written communication. I apply the notion of orthographic repertoire to examine three young women's spelling of Wolof as socially embedded practices. The analysis covers three different sets of interactional data: 1 ) texting by Senegalese university students, 2) discussion forum posts, and, 3) transnational digital family interaction. The spelling practices are examined with reference to the colonial history of spelling in Senegal, other contemporary informal literacies in West Africa, and the sociolinguistic context of the writers. The paper shows that the different spelling resources related to the multilingual and mediated nature of their writing are drawn upon as the three young women engage in digital literacy practices including Wolof.

Keywords: multilingualism, SMS, texting, discussion forums, Messenger, Senegal, Wolof, French 


\section{Introduction}

In her account of orthographies in West Africa, Judith Irvine (2019: 47) states: «Exploring early orthographies for West African languages [...] reveals some of the complexities and ideological tensions that make orthography - as a basis for print literacy - a socially embedded set of practices.» Irvine shows how the colonial administration paved the way for an orthography of the West African languages based on standard French through rejecting the already existing Ajami literacy, and disregarding African perspectives and attempts at spelling for instance Wolof in line with phonemic principles. After independence, the Senegalese parliament voted new standards for Wolof and other national languages, breaking with the French orthography, but sticking to the Roman script. These written standards are however rarely observed, despite their use in literacy programs, and to a certain extent in formal education (Lüpke 2018). Instead, there are different spelling practices and digraphia (Grivelet 2001) or biscriptality (use of different scripts to write a language, Bunčić et al. 2016), as Arabic characters continue to be used to write a number of West African languages (see for instance Lüpke \& Bao-Diop 2014). Other languages have their proper scripts (e.g. N'ko, Vai, Tifinagh). During the last two decades, digital communication has become important as everyday literacy in Senegal. This interaction is often multilingual. In this paper, I will focus on such practices, and more specifically on digital writing in Roman script, as writers bring different languages and different spelling practices together. The aim is to examine the impact of plural digital literacies on spelling practices of Wolof as a socially embedded set of practices (cf. Irvine 2019, Sebba 2007). In order to do so, digital interaction will be analysed through the notion of orthographic repertoires. The repertoire concept invites us to look at language practices as drawing on diverse and fluid resources while participants move between different spaces with different language regimes (cf. Busch 2012).

The paper starts with a presentation of Wolof orthography in Senegal in a historical perspective. Second, with reference to other studies of informal writing in West African languages in Senegal, Mali and Gambia, it discusses the notion of orthographic repertoires and justify its use in this paper. The analysis follows, starting with the presentation of a French-Wolof phrase book from the $19^{\text {th }}$ century (Descemet 1864). Then continues the investigation of digital writing by three writers representing different practices: 1) interpersonal texting by Senegalese University students (Lexander 2011a, b, 2012), 2) digital discussion forum posts (Lexander \& Lopez, 2007, forthc.), and transnational digital family interaction by Senegalese background families in Norway (Lexander \& Androutsopoulos 2019). What orthographic resources do these writers draw on to write Wolof in their messages? How do these practices relate to and gain significance from other practices of writing in West Africa? 


\section{Language and literacy in Senegal}

There are 25-30 languages spoken in Senegal, according to different sources (Cissé 2005; Mc Laughlin 2008a). This imprecise number reflects the multilingual nature of communication in the country, and the lack of definite boundaries between the language practices (Dreyfus \& Juillard 2004; Lüpke 2018). Wolof is the spoken lingua franca in the country, and $80-90 \%$ of the Senegalese population use it (Mc Laughlin 2008a). Still, speaking Wolof often means translanguaging (García 2009): speakers use their entire multilingual repertoire when communicating, often without referring themselves to defined languages. Instead there is a "languaging continuum that is accessed" (ibid.: 47) to interact, as speakers draw on different linguistic resources to interact. In the cities, this way of speaking is called urban Wolof (Mc Laughlin 2001; Swigart 1992). Translanguaging also appears in writing, and this is not a recent phenomenon (Mc Laughlin 2008b). I will therefore start with an account of the history of Wolof orthography in Senegal based on Irvine's (2019) paper and additional sources.

Reading and writing Senegalese languages in the Roman script goes back to colonial times. Extensive Ajami traditions already existed before colonialization, in particular in Wolof (called Wolofal) and Pulaar, but the lead-language writing (Lüpke \& Bao-Diop 2014) in Arabic script was not taken into account when Europeans were to "reduce" African languages to writing. Traces of the misjudging of Ajami is found even today, as West Africans who use Arabic script, whether to write Arabic-language texts or Ajami texts, are routinely classified as "illiterate" in official statistics (Irvine 2019: 46). With an overwhelming Muslim majority, many Senegalese acquire the Arabic script through Qur'anic schooling, and even though the Wolofal practices often relate to Islam, and initially did not appeal to Christian missionaries, Lexander (2011a) reports examples of Wolofal by missionary organizations in contemporary Senegal. These practices have not been standardized although there have been such efforts (Evers 2011, Lüpke \& Bao-Diop 2014), and they are observed in particular in areas that constitute the heartland of the Mourid Sufi brotherhood (Mc Laughlin 2014: 31). They are also common in the linguistic landscape (Lüpke forthc.).

Colonial authorities and missionaries introduced literacy in a combined effort: "Standardisation, writing, notions of orthographic "correctness," and printing combined in a single project" (Irvine 2019: 27). The Catholic missionary Aloyse Kobès came to Senegal in 1849 and set up a printing press where several works were published: prayers and liturgical materials in Wolof, French/Wolof bilingual catechisms for adults and children, a Wolof-French dictionary, and a Wolof grammar (Irvine 2019: 29, referring to Kobès 1869; O. Abiven, Annales religieuses de St Joseph de Ngasobil, 1848-1929, DAK). Interesting is the fact that Kobès used a largely phonemic orthography, not French spelling, to write 
Wolof, but this orthography did not gain currency. Also the Wolof orthography proposed in 1858 by David Boilat, a Catholic missionary of mixed-race background and a native speaker of the language, was rejected by the French authorities, among other things because it used "signs outside the French alphabet" (Faidherbe 1887: 6, cited in Irvine 2019: 37). In fact, the spelling that became familiar to Wolof-speaking Africans was that of Louis Faidherbe, governor of French Senegal 1854-61 and 186365. His system conformed to French spelling conventions and was used for recording names of persons and places (Irvine 2019: 39). The African targets of these efforts did not necessarily share the Europeans' motivations, as they rather wanted to learn a European language, not be taught to write a language they already knew, by an outsider who scarcely spoke it (Irvine 2019: 30). These factors surrounding the introduction of Roman script for writing Wolof still influence Wolof spelling: French orthographic norms inform informal writing, and the motivation to learn to write in standard Wolof is low. Political measures have not raised the status of Wolof vis-à-vis the official language French, which is still the sole language of instruction in formal schooling, with the exception of Ecoles FrancoArabes where Arabic is also taught (D'Aoust 2013).

Language policy and orthography continued to be hotly debated political issues in Senegal. Already in 1937, Léopold S. Senghor, who became the first president of the independent nation in 1960, called for the introduction of national languages in the school system (in Senghor 1964: 18). Descriptions of Wolof were carried out by Senghor and other political researchers like Pathé Diagne. In 1959, the year preceding Senegalese independence, the anti-imperialist Fédération des Etudiants d'Afrique Noire en France, with among them another future Senegalese president, Abdoulaye Wade, published Ijjib Volof, one of the first Wolof syllabaries (Prinz 1996). This publication would make up the base for the official transcription of the language, together with the conclusions from the Unesco expert meeting on the unification of alphabets of national languages in Bamako in $1966^{1}$. The system based on French spelling conventions was rejected, and the standard orthography for Wolof and 5 other national languages (Pulaar, Soninké, Mandinka, Joola, Seereer) all were to follow phonetic principles. These standards were voted by the Senegalese National Assembly in 1968, 1971 and 1985 (Cissé 2005), and the Centre de linguistique appliquée de Dakar (CLAD) was founded in 1963 to study the Senegalese languages, alongside French and English. Violations of the orthographic norms in publications could be punished with imprisonment or a very high fine (Hesseling 1985), but this strict political and national language policy did not lead to a broad use of Wolof orthography in informal writing. This was mainly because the former colonial language French was kept as the official language and only language of instruction in formal schooling. Experimental classes in national

\footnotetext{
${ }^{1}$ Some of the differences between $l j j i b$ and standard transcription are $\langle\ddot{e}\rangle(\langle a ̈\rangle$ in $\mid j j i b),\langle w\rangle(\langle v\rangle$ in $\mid j j i b)$ and $\langle x\rangle$ $(<h>$ in ljjib) (cf. Prinz 1996: 40).
} 
languages have given good results, but have not turned into changes in the school system. Until 2001 the six national languages voted in 1968 remained the only languages with such status, but this changed with the new constitution following Abdoulaye Wade's victory in the presidential elections of 2000. In this constitution, every codified language obtains the status of national language. In December 2016, there were 21 codified and hence national languages in Senegal (personal communication with Adjaratou Sàll, 2016). The national languages are used in literacy programmes, aiming at the half of the Senegalese population that are considered illiterate (Unesco 2020), and Wolof, Pulaar, Joola and Seereer are taught as subjects at the University of Dakar. These languages rarely appear in writing in formal contexts, however. Publishers who promote national languages have published some novels and some poetry in Wolof, but they have not reached commercial success (Keita 2013).

Because French was kept as the official language after independence, the spelling of Wolof toponyms, for instance, is in accordance with French orthography: Niokolo Koba, Kedougou (Cissé 2005). This spelling is different from Wolof orthography, which would be Ñokolo Koba, Kedugu, but not radically dissimilar. In particular the use of $\langle\mathrm{K}\rangle$ instead of the possible French-like alternatives $\langle\mathrm{C}\rangle$ or $<Q u>$ diminishes the difference; if one can read one of them, one can read the other too. A third version of spelling Wolof names are found in Gambia, where English serves as lead language. Hence, the family name written Diop in Senegal, is written Job in the Gambia and Joop in standard Wolof (see Mbodj 2002: 55). Heterographic practices thus still prevails in Senegal and neighboring countries Mali and Gambia. We find them in personal notebooks and other personal writing (Mbodj-Pouye 2013, Juffermans 2015), in the linguistic landscape (e.g. Mc Laughlin 2014), and in digital writing (e.g. Lexander 2011, Mc Laughlin 2014). Irvine's statement about literacy in colonial times is still valid today: "What many African pupils ended up acquiring was not just literacy itself, but a repertoire of literacy practices involving two or more quite different systems" (Irvine 2019: 44). We will now turn to the notion of repertoire and its usefulness in analysing spelling practices.

\section{Orthographic repertoires}

The notion of repertoire has increasingly been embraced by sociolinguists to account for diverse practices where speakers and writers draw on multiple language resources. It shifts the focus from languages as bounded entities that can be switched back and forth to a more fluid perspective on language as practice, in line with recent developments that have supported the notion of translanguaging (García 2009). Several studies of literacy practices in West Africa consider writing 
through the notion of repertoire "as lived and living experience" (Lüpke \& Storch 2013), and I will present some of them here, before I turn to the use of the concept in this paper.

John Gumperz introduced the "verbal repertoire" as a set of resources shared by a speech community: "the totality of linguistic forms regularly employed in the course of socially significant interaction" (Gumperz 1964: 137). Thus, "[i]t connects language with the social and the cultural, and at the same time with the individual” (Lüpke \& Storch 2013: 349). In Brigitta Busch's work (2012), the linguistic repertoire is understood from the perspective of the individual, and not from that of the speech community. According to this biographical approach, language practices are subjected to the time-space dimensions of an individual's history and biography, and has four characteristics: 1) Languages are understood in relation to each other, as forming a heteroglossic whole. 2) Meanings people attribute to languages, for instance in constructing social identity, are linked with their personal experiences, like migration, and may change throughout life. 3) People participate in different spaces with different language regimes, i.e. rules and language ideologies, and bring with them evaluations from other spaces. 4) It points both backwards, to memories that can be evoked, and forward, for instance in language learning. In this paper, these four characteristics will be investigated with regards to the orthographic repertoire: How is Wolof understood in relation to other languages, and, more specifically, how is the orthography of Wolof understood in relation to the orthography of other languages, as part of a heterographic whole? What meanings do people attribute to different ways of spelling Wolof? What evaluations from other spaces do people bring with them to informal digital interaction? In what ways do the different ways of spelling Wolof point backwards and forward?

The association of language to the social, the cultural and the individual (cf. Lüpke \& Storch 2013) has been investigated through the repertoire notion in several studies of literacy in the West African context. Aïssatou Mbodj-Pouye and Cécile van den Avenne $(2007,2012)$ analyse multilingual written repertoires of low-literate writers in Mali as they appear in hand-written personal notebooks and letters. These writers deal with "unbalanced and mixed repertoires": they may write in French although they do not speak the language, and they copy Arabic words without necessarily knowing their significance (Mbodj-Pouye \& van den Avenne 2007: 104). They draw on graphic and discursive resources, like punctuation, underlining, and colour of ink, linguistic and cultural translations, to produce texts that are fluid in language and script choice.

In his study of similar heterographic literacy practices in the Gambia, Kasper Juffermans (2015, chapter 6) focuses on spelling in Mandinka. When he receives a text in Mandinka, produced by a writer who has attended adult literacy classes in this language, and asks an English-educated person to translate it to English, he instead gets a respelling. The author of the respelling claims that he has 
provided a more correct way of writing Mandinka than the original author, even though the latter remains relatively close to the official norms adopted by the government. The spelling is thus less "correct" as compared to Mandinka orthography, but has higher social status, as it is connected to English education. The differences in spelling practices lie in the writers' "different learning histories, their educational biographies, and their different valued routes to and investments in literacy" (Juffermans 2015: 138).

The studies by Mbodj-Pouye \& van den Avenne and Juffermans show how the relation between ideology, language and script is fluid and locally embedded. This point is also made in Fiona Mc Laughlin's (2015) study of the linguistic warscape of Northern Mali, where a third script appears alongside Arabic and Latin. Tifinagh is used for the Tamasheq language, mainly spoken in the north, the region that was claimed independent in 2012 during the armed uprising in the country. The use of the script is mainly emblematic, relating to political views in a time of political turmoil. Mc Laughlin (2014) also raises the issue of spelling in her study of "Senegalese digital repertoires", through a case study of comments on the web portal Seneweb. She claims that "[i]n attempting to reconstruct home virtually, Seneweb writers circumscribe their more diverse repertoires to mirror the linguistic environment that they have left behind" (Mc Laughlin 2014: 30). This includes language practices located between Wolof and French that allow more liberty of expression because they are not subject to the same normative judgments as French is (2014: 31). The Seneweb texts mainly follow the norms of French orthography, but there are instances of alternative spelling adopted from standard Wolof, indicating "an aspirational orientation towards a different norm" (2014: 34). This echoes Lexander's (2012) study of texting, where such instances of spelling from standard Wolof also appear, and we will look more into such "aspirational orientations" in the present paper.

To study transnational digital interaction in a transnational Norwegian-Senegalese context, Kristin V. Lexander \& Jannis Androutsopoulos (2019) coin the notion of mediational repertoires. This is a socially and individually structured configuration of both semiotic and technological resources to consider digital communication as drawing on linguistic, multimodal and graphic affordances related to different digital means. The advantage of this perspective is that the use of linguistic resources is considered in light of the choice of communicational tool and modality, and the interlocutors in question. Also the use of orthographic resources is affected by these factors, and in the current paper, I will take into account the mediational repertoire, to study spelling as a socially embedded practice (Sebba 2007). I will use the term orthographic repertoire in line with Busch's (2012) linguistic repertoire, as encompassing spelling practices (formally regulated or not) related to different languages that the writer knows (to greater or lesser extent), not as separate entities, but in relation to one another. The meaning of spelling forms are linked to personal experience and people 
participate in different spaces that are more or less regulated with regards to spelling, with different orthographic regimes (Sebba 2007). The orthographic repertoires are both historically situated, as well as innovative. While the introduction of the Roman script during colonial times still influences spelling in present day Senegal, the recent introduction of digital communication tools has provided new perspectives and practices. Not the least has it increased Wolof writing by the three writers whose practices are discussed here.

\section{Writing Wolof in a heterographic context}

Digital communication has opened up new spaces for written communication in Senegal, and in the transnational Senegalese context. Here, the writers make use of their entire linguistic repertoire (Lexander 2011b, 2012, Lexander \& Androutsopoulos 2019), and, as we will see, their orthographic repertoire. In order to consider orthographic repertoires as related to individual biographies, three participants will be in focus here, representing three groups of writers: a young, urban Senegalese university student (4.2.), a discussion forum member (4.3.), and a young woman who immigrated to Norway as a child (4.4). We will look at the digital literacy practices in which they engage through analysing messages sent by and to them. The practices will be considered in relation to practices of writing Wolof in the past, exemplified by Louis Descemet's phrase book (4.1).

\subsection{Spelling practices in a French-Wolof phrase book}

In 1864, the métis ${ }^{2}$ Louis Descemet published a French - Wolof phrasebook with 1.200 phrases in French translated into "Saint Louis Wolof". In her study of Descemet's phrasebook, Mc Laughlin (2008b) shows that the mixing of Wolof and French is not a recent phenomenon in Senegal; what Descemet calls Saint Louis Wolof is in fact Wolof with a lot of linguistic material from French. In his introduction, Descemet (1864: 5) explains his choice of orthography as the simplest possible to make the reader understand. The aim of the book is to teach French to the "indigènes", which means that the Wolof phrases are only there to make the French phrases comprehensible. All data will be presented along with standard transcription for comparison, and translation into English (Wolof in bold, French in italics Wolof-French in bold italics and English in regular font).

\section{Example 1: Descemet's phrasebook (1864: 27)}

Original Socola silé défarou niou ko bou bakh

\footnotetext{
${ }^{2}$ Mixed (of both European and African descent). The métis made up an influential elite in Saint-Louis, one of the most important cities in French West Africa.
} 


\author{
Standard Sokola sile defaru ñu ko bu baax \\ Translation 'This chocolate is not well made' \\ Original Ndakh café-gou for-nà bou doy? \\ Standard Ndax kafe gu for na bu doy? \\ Translation 'Is the coffee too strong?'
}

In these two examples from the phrase book, there is morphologically integration of French in the Wolof phrases so that they appear as part of a heteroglossic whole. The integration of the two languages is strengthened by the use of one spelling regime, that of French. We thus observe the use of $<$ ou $>$ for $/ \mathrm{u} /,<\mathrm{ni}>$ for $/ \tilde{n} /$, and $<\mathrm{kh}>$ for $/ \mathrm{x} /$. The spelling further indicates that the French words are pronounced differently in Saint Louis Wolof, as chocolat has been adjusted to <socola>, signaling deviance from the French standard (/s/ instead of $/ \mathrm{J} /$ ).

As described in section 2, the orthography observed in Descemet's phrasebook is also found in other text books and dictionaries written for other African languages by French colonial administrators and missionaries (see also Van den Avenne 2012). However, there was a competing norm based on phonemic principles that Descemet potentially could have chosen to use. Descemet's aim is however not to promote a spelling norm for the Wolof language, but to communicate. This is also the argument used by the writers of Wolof studied here, as the spelling principles applied by Descement are still prevalent in many informal literacy practices, including digital writing. One important reason for writing Wolof based on French orthography is of course that many Senegalese have learnt to read and write French only, since Wolof is not being taught in school. However, this cannot be the only explanation, as also university students who have studied Wolof in University use such spelling (Lexander 2011a, b; 2012). We will now look at their practices.

\title{
4.2 Senegalese university students writing Wolof in SMS messages
}

Senegalese university students make up a group that is particularly interesting for the study of orthographic repertoires because they take part in practices of writing standard French daily while at the same time learning to write a national language is a compulsory part of some university degrees. Moreover, these students engage in informal, multilingual literacy practices mediated by digital tools, and they text relatives and friends who do not necessarily read and write French. The data from the 
students analysed here was collected in Dakar 2005-2007 through interviews (individual and focus groups), observation and text collection (Lexander 2011a, b; 2012). The full corpus consists of 496 SMS messages, 9 instant messaging chats, and 30 emails from 15 young Senegalese, most of them university students. We will now look into the practices of one of them, Magatte.

Magatte lives in the Dakar suburb and speaks Wolof and French, as well as some Arabic related to her Qur'anic schooling. She also learnt English and Spanish through her public schooling, and she studied Wolof in University. Magatte calls the Wolof taught in University "real Wolof", and says it "made her laugh". Her urban language practices are different from this Wolof, and in her digital interaction, she makes use of what she calls "wolof francisé", Wolof written in line with French orthography, and drawing on different linguistic resources. The example 2 is a joking message sent to a male friend that she had not seen or heard from in a while.

\section{Example 2: SMS data 2006}

Original slt coma tu va si lo nék nak g ta 90.3 bayi gua ma de khana tu a part bou bèss?

Standard Salut, comment tu vas, si loo nekk nak, j'ai ta 90.3, bàyyi nga ma de, xanaa tu as partenaire bu bees?

Translation 'Hi, how are you? So, what are you in (i.e. how are you)? I have your nostalgia. You've really left me, do you have a new partner?'

We find several features of French-inspired spelling in this exchange. In addition to the $<$ ou $>$ in $<$ bou $>$, we find kh in <khana>, and a mute $u$ in $<$ gua $>$, probably to indicate the pronunciation [g], but not really necessary, as in French a $<\mathrm{g}>$ preceeding $<\mathrm{a}>$ is pronounced $[\mathrm{g}]$. Magatte says that she uses French spelling norms because her interlocutors have not studied the official orthography and she is afraid of not being understood if she writes standard Wolof. Like the transcription in accordance with standard Wolof shows, it does not differ from the French-based spelling to the extent of becoming unreadable. It is probably more a question of habits, since people in Senegal are used to reading Wolof words according to French orthographic rules; as we have seen, with these spelling practices she enters the tradition of writing Wolof in contact with French going back to the colonial times. This argument is strengthen by the fact that the receivers' lack of understanding does not seem to hinder creative spellings. Even rebus spellings appear in Magatte's SMS message. When she states that her friend has left her and found a new partner, she is joking. This is underlined by the joking spelling in $<\mathrm{g}$ ta $90.3>$. The number $\langle 90.3>$ refers to the frequency of the Senegalese Radio station named Nostalgie. Since in Wolof, people say Namm naa la, 'I have your nostalgia', this code refers to the 
calqued French expression j'ai ta nostalgie (<g> here representing j'ai, 'I have'). In fact, it was the receiver of the message, also a participant in the study, who showed this message to me and laughingly explained its significance. This kind of creative spelling is obviously not something Magatte would use to all her interlocutors, like older parents, for instance, but to close friends of the same age.

In Magatte's SMS messages we also find spelling aimed at representing spoken language. We find several examples of spelling that are intended to reflect Senegalese pronunciation of French (loan)words, thus mirroring oral practices. In example 4, <garraw $>$ is the representation of the morphologically and phonologically integrated French adjective grave ('serious'), pronounced /garaw/ in Wolof.

\section{Example 3: SMS data 2006}

Original Goce saa maron bi garraw na. Yagni léék saa khaliss. Je s8 in the bus. Bisou. Standard Gosse, sa marron bi garaw na. Yangi lekk sa xaalis. Je suis in the bus. Bisou. Translation 'My friend, your brown (outfit) is seriously nice. You eat your money. I am in the bus. Kiss.'

Likewise, in other text messages, the French word trop, for instance, is written <torop $>$ to signal the phonological integration of the borrowing, or $\langle$ trope $>$, where a mute e is added in the end to signal that the $p$ is pronounced (which it is in urban Wolof but not in standard French). The orthographic principles of French standard are thus adapted to the Senegalese context, in the same way as the spelling of <socola> (to represent Saint Louis Wolof pronunciation of chocolat) in Descemet's phrase book. Throughout the messages, Magatte and her friend draw seamlessly on linguistic resources that can be considered as both Wolof, French, and English. Magatte's fellow students also underline the blurred differences between languages in in the interviews, and when explaining language use in a text message he had written, one student said: "chou boy, c'est quelle langue, ça? On utilise comme ça" ('chou boy, what language is that? We use it like that'). Actually, this translanguaging in itself may be facilitated by the use of one type of spelling. It appears as more seamless and may indicate that the writers do not consider their writing as switching between languages. This is what Friederike Lüpke (forthcoming) names language-independent writing.

Sticking with this spelling is somewhat unmarked, while writing in standard Wolof would stand out as marked, but marking what? There are also features associated with standard Wolof in the message in example 3. Wolof orthography encompasses many double vowels that are not found in French, and the repeated use of <saa $>$ ('your') in this message can be seen as referring to this. 
A third graphic resource in example 3 is the creative spelling of $\langle s 8>$ for $\langle$ suis $>$ ('[I] am'). This spelling represents a kind of creativity that is often associated with digital interaction, a group of practices consisting of truncated forms, specialized acronyms and other unconventional spelling forms. The practices also appear in other contexts and they are more an expression of the fluidity in writing than motivated by specific media. In the Senegalese students' text messages, these forms are frequently used for French words. The spelling $<s 8>$ is used in 37 of the 496 text messages from Senegal, outnumbering <suis>, which appears six times. But, while respelling of French is common, Wolof is rarely abbreviated. In the SMS corpus, only some examples of such spellings are found: $<\mathrm{dwnti}>$ for déwénati (omission of vowels, greeting used for the feast marking the end of Ramadan), and $<T>$ in $<$ KoriT > (korite, feast marking the end of Ramadan). There is also multiplication of letters, like in $<$ nobaaaaté $>$ ('in love'). In the Senegal-based discussion forum we find more of these practices.

\subsection{Writing Wolof in a Senegal-based discussion forum}

Public discussion forums represent a communication form that is quite different from SMS messages. While texting usually includes two interlocutors, or at least a restricted number of participants, anyone can read what a forum member posts, and anyone registered in the forum can react to it. We will now turn one such forum, looking at the practices of "Oumou". Oumou was a member of a Senegal-based discussion forum, whose posts were analyzed qualitatively and quantitatively along with around 500.000 other posts from the forum, posted between 2002-2014 (Lexander \& López 2017, forthcoming). We have not interviewed her, and therefore we do not know much about her personal history, which makes it hard to capture her orthographic repertoire. I nevertheless include her profile in the analysis, because her discussion forum practices are interesting for comparative purposes, and her messages give us information through both the spelling practices and the metacomments there produced.

Oumou is one of the top 3 contributors to the discussion forum analyzed. According to the scarce personal information she signals in the forum, she is a young woman. Oumou uses different spelling forms; a lot of unconventional spelling of French words, and also of Wolof. She seems to have a special status in the forum, as the other posters often asks her to explain acronyms. One of the acronyms shes uses and explains is $R B T$, which appears to be the Wolof version of LOL ('laughing out loud'). It is based on the popular expression rée ba tass 'laugh until exhausted' (see Lexander and López forthc.). At times, new members of the forum ask for the signification of $<$ RBT $>$, indicating their unfamiliarity with the acronym. In the example 4 , she is asked to explain a similar acronym, namely $<$ rbp $>$, which has more or less the same meaning, but is less frequently used. The use of such 
acronyms and truncated forms seems to be facilitated by the dynamics of the discussion forum, and by the meta-discussions that take place there, so that it has become a shared spelling feature of this specific online community (I have not observed the use of RBT in any other digital data).

The language practices in the discussion forum are quite similar to the ones observed among University students. Some posts are in Wolof, others contain a diversity of linguistic resources, and some are written in French. In example 4, two consecutive posts from a longer thread are reproduced. The first is written by Oumou, the second by another forum member. Like the Magatte's SMS messages, they have playful content, and refer to "events" that only take place through their online communication, like the reference to medication and servicing by another member.

Example 4: Discussion forum data 2005 (from Lexander \& López forthc.)

Oumou dafa fekk meuno fass grand, ya fass et fass tagou nala, mais désintoxication bi, dafa melni amoulo garabam dé gnou mougnko bokk???

t’as une drôle de façon d'écrire le wolof

Standard Dafa fekk mënu fass, grand, il y $a$ fass $e t$ fass

Tagu naa la, mais désintoxication bi, dafa mel ni amuloo garabam dé Ñu muñu ko bokk???

Tu as une drôle de façon d'écrire le wolof

Translation 'it's because you cannot ride a horse, my friend, there is riding a horse and riding a horse

I say goodbye to you, but the detoxification, it seems that you don't have any of that medication

so, let's wait???

you have a strange way of writing Wolof'

Other member dina oute garabam dé ... difficile à lire ?

fanane ak diam soxna ci ... demain tu me diras si tu aimes les saillies de [nickname] ... rbt ! tu m'explikeras également rbp 
Standard

Dinaa ute garabam dé ... difficlie à lire ?

Fanaan ak jàmm soxna si ... demain tu me diras si tu aimes les saillies de [nickname] ... rbt! Tu m'expliqueras également rbp

Translation 'I will get you the medication for sure...difficult to read?

'sleep in peace, lady...tomorrow you will tell me if you like the servicing of [other member]...lol ! you will also explain rpb to me'

The first part of Oumou's post is in Wolof, using some linguistic material from French that can be considered as commonly used when speaking Wolof. In the last phrase, however, she writes in French, to comment on her co-member's spelling of Wolof, which she finds "drôle", funny or strange, indicating that this spelling is subject of normative judgement. Oumou writes Wolof according to French spelling (e.g. <eu> for /ə/, ou for $/ u$ ]/), while her interlocutor draws on both French and Wolof orthography, using $<x>$ from standard Wolof in $<$ soxna $>$.

If we return to Juffermans' (2015) analysis of the status difference between standard Mandinka orthography and English-based spelling, the digital spelling of Wolof emerges in a similar situation. As Juffermans explains, there is lack of enregisterment of the orthography - people don't know it. Since it is taught in literacy classes for adults, the use of the orthography signals lack of formal schooling. The situation is similar in Senegal. However, the SMS messages collected in Dakar 2005-2007 were in part written by students who had studied Wolof (or Pulaar) as subject in formal schooling, in University even. They were thus familiar with the standard, at least to some extent. But even if they were familiar with it, the lack of enregisterment among their interlocutors could arouse negative associations. The university students do represent a different view of that upheld by Jufferman's English-educated participant; they consider standard of Wolof as «correct» and French-inspired spelling as «incorrect». Still, they use the latter to adapt to the interlocutors, probably just as much to their ideologies, and the reaction they can get on standard Wolof spelling, as to their understanding. In example 4, the co-member wants to know what Oumou means by "drôle", if it is difficult to read, but she claims that it is not difficult, only "spécial".

The $\langle x>$ is one of the traits of official Wolof that does not have a real equivalent in French, and it may have achieved a status as a marker of 'other-languageness' or iconicity (Sebba 2007), standing out as "spécial". In the discussion forums <wax > is in fact used quite extensively, but still much less than the French-based spelling <wakh>. Also in the discussion forum analysed by Mc Lauhglin (2014), $<x>$ 
appears, and she suggests that this orthography may be more widely adopted for practical reasons (Mc Laughlin 2014: 34). This seems already to be happening to some extent, but it is worth noting that the statistical analysis of the discussion forum posts shows that the use of $\langle x\rangle$ as compared to $<k h>$ did not increase from 2002-2014 (Lexander \& López forthc.). Also in the corpus collected with Norwegian-Senegalese families 2017-2018, we see the Wolof / $x /$ beging spelled both $\langle x\rangle$ and $\langle k h\rangle$, and we will now turn to these data.

\subsection{Writing Wolof in a Norwegian context}

An important aspect of digital communication is the way it enhances the capacity to interact transnationally. Language and spelling practices can be shared across the world, and Wolof speakers can communicate with each other despite geographical distance. This is important for migrants like Awa, who emigrated with her mother and brother when she was little, and the three of them now live in Norway with two younger siblings. In this last part of the analysis, I will present interview and interactional data, including WhatsApp, SMS and Messenger conversations, collected in Awa's and three other Senegalese background families in Norway 2017-2018. No one in Awa's neighbourhood speaks Wolof, it is only used within the household. However, with her mother and siblings, Awa solely uses the language in spoken conversation, alongside Norwegian, Arabic and English. It is uniquely with relatives and friends from Senegal, living in different parts of the world, that she writes Wolof. Awa first learnt to read and write in Norwegian, in the public school system, and later she learnt English and French. She has also attended Qur'anic school and learnt some Arabic. She was never taught Wolof, but says that she writes it as she reads it in messages she receives. Awa's mother rarely writes Wolof, she prefers French, Norwegian and English. She claims that this is related to the fact that she never received schooling in the language. Most people just write it "as they hear it", she says (interview data 2017).

The extracts 5 and 6 below come from a Messenger conversation between Awa and a young Senegalese friend of the family who studies in Germany. They draw on different linguistic resources and different orthographic resources to interact.

\section{Example 5: Messenger data 2016}

Friend Yow xana neko classe!?

Standard Yow, xanaa nekko classe!?

Translation 'are you not in class?' 


$\begin{array}{ll}\text { Awa } & \text { Nope } \\ \text { Awa } & \text { Pare na } \\ \text { Standard } & \text { Pare na } \\ \text { Translation } & \text { 'I'm done' } \\ \text { Awa } & \text { Depuis } \\ \text { Standard } & \text { Depuis } \\ \text { Translation } & \text { 'Since' } \\ \text { Awa } & \text { 12:00 } \\ \text { Awa } & \text { Unhuuun } \\ \text { Friend } & \text { Donc yangui sa gale!? } \\ \text { Standard } & \text { Donc, yaa ngi sa galé } \\ \text { Translation } & \text { 'So, you're at home?' } \\ \text { Awa } & \text { Nope }\end{array}$

The excerpt starts with the friend asking if Awa is in class, using the $<x>$ from standard Wolof, as discussed above. In fact, this specific friend regularly uses the $\langle x>$ in their Messenger conversation, which stretches over several years; and Awa showed me an example of this, she pointed it out as standard. Even though she has never learnt to read or write it, and do not live in Senegal, she knows that this is Wolof orthography. This supports the assumption that it has acquired some iconicity. In the next turns, Awa replies to the question, drawing on English, Wolof, French, and linguistic resources that are not associated with specific languages (i.e. $\langle 12.00\rangle,\langle$ Uhuuun $\rangle$ ). Her friend does not stick to standard Wolof alone; he introduces a mute $\mathrm{u}$ to signal the pronunciation of $\mathrm{g}[\mathrm{g}]$ in <yangui> in his follow-up question. This diversity is characteristic of his Wolof spelling throughout; it uses features from both standard and French-based spelling. Together with interaction with other family friends, uncles and aunts, this dialogue make up Awa's main literacy practices involving Wolof. This is also her main access to the spelling of the language. When asked if she has learnt to write Wolof, she answers "mm, jeg ser hvordan de formulerer seg, og så bare kopierer jeg", 'mm, I see how they formulate, and then I just copy'. Looking at her practices, she does not seem to copy only. In 
another message to her friend in Senegal, she writes the Wolof expression naka mu <nakamouuu>, multiplying the last letter:

Example 6: Messenger data 2016

$\begin{array}{ll}\text { Awa } & \text { Nakamouuu } \\ \text { Standard } & \text { Naka mu } \\ \text { Translation } & \text { 'How are you?' } \\ \text { Friend } & \text { Sant fils } \\ \text { Standard } & \text { Sant } \text { fils } \\ \text { Translation } & \text { 'I thank the Son' }\end{array}$

This is the only example of the multiplication of letters for expressivity in a Wolof word in their conversation. However, Awa also uses this spelling practice for expressions like <yasssss $\rangle$, <Yeahhh>, $<$ Skypeeeee $>,<$ Woahhh $>$. She applies a spelling practice used across different linguistic resources. Overall, the multiplication of letters does seem to be more frequent in the cases discussed here than many other forms of creative spelling. Based on the participants' statements, one reason may be that this form of spelling is less disturbing for the comprehension than for instance new acronyms and truncated words. Thus, through their uptake of these creative spellings inspired by different types of unconventional writing in digital interaction, mixing it with different spelling regimes, Senegalese local and transnational writers engage their entire orthographic repertoire, to refer to both global and local literacy practices, and not necessarily to specific languages.

\section{Conclusion}

While the colonial missionaries' aim was to reduce African languages to writing (cf. Irvine 2019), West African writers rather diversify their practices, and digital technology enhances the spread of this diversity. The orthographic context Senegalese writers like Magatte, Oumou, and Awa find themselves in today is not that different from the one in which Descemet found himself when he edited his phrasebook. There is an unrecognized Arabic-based Wolofal spelling, there is an orthography, now official, based on phonemic principles, but without much institutional support, and there is a strong tradition of writing Wolof as following French spelling norms. 
Following Sebba's theory of spelling as social practice (2007), implying that spelling choices bear social meaning, the orthographic repertoire is an important resource in mediated communication. In the Senegalese writers' repertoire, French orthography, Wolof orthography and creative spellings are related to each other, and the writer can draw on the different elements to for instance enhance comprehension (make use of principles for standard French), stand out as non-French (make use of features from standard Wolof) and/or show knowledge of the codes associated with digital writing. The spelling practices described in this chapter thus show that writers draw on different parts of their orthographic repertoire, within the same interaction, and even while writing a single short text. The writers transgress boundaries between different standards and draw on them without necessarily following them, and the resources are not necessarily acquired through schooling.

In informal digital interaction, writing is less regulated than in other orthographic regimes (Sebba 2007), like the educational context, and the norms applied in regulated spaces are both contested and applied. Writers do not seek to copy French spelling; they adjust it and add features from African language standards, making their written discourse stand out as singular. Spelling can be used as an efficient tool to express important aspects of people's lives and intentions, like skills, identity, and ideologies, for instance towards languages as fluid. Moreover, like the phrase book from the colonial times shows, today's spelling of Wolof points back to French linguistic imperialism, but it also points forward, through the frequent use of respelling of French words and the creative spelling of Wolof words. Juffermans concludes his chapter on Mandinka spelling in Gambia, that spelling Mandinka in peri-urban Gambia is always spelling in the presence of English (2015: 140). For Wolof, we could say that writing Wolof digitally is rarely solely writing Wolof, it is usually a multilingual multi-orthographic endeavour.

\section{References}

Bunčić, Daniel, Sandra L. Lippert, \& Achim Rabus (eds.) (2016). Biscriptality: A sociolinguistic typology. Heidelberg: Winter.

Busch, Brigitta (2012). The linguistic repertoire revisited. Applied Linguistics 33(5): 503-523.

Cissé, Mamadou (2005). Langues, Etat et société au Sénégal. Sudlangues 5: 99-133.

D’Aoust, Sophie (2013). Écoles franco-arabes publiques et daaras modernes au Sénégal : hybridation des ordres normatifs concernant l'éducation. Ecole, alphabétisation et lutte contre l'illettrisme 12: 313-328. 
Descemet, Louis (1864). Receuil d'environ 1,200 phrases françaises usuelles avec leur traduction en regard en oulouf de Saint-Louis. Saint-Louis: Imprimerie du Gouvernement.

Dreyfus Martine \& Juillard, Caroline (2004). Le plurilinguisme au Sénégal. Langues et identités en devenir. Paris: Karthala.

Evers, Cécile (2011). Orthographic policy and planning in Sénégal/Senegaal: The détournement of orthographic stereotypes. Working Papers in Educational Linguistics 26 (1): 21-51.

García, Ofelia (2009). Bilingual Education in the 21st century: a global perspective. Malden MA, Oxford: Basil/Blackwell.

Grivelet, Stéphane (ed.) (2001). Digraphia: Writing Systems and Society: Special issue. International Journal of the Sociology of Language, 150.

Gumperz, John (1964) Linguistic and social interaction in two communities. American Anthropologist 66 (6): 137-153.

Hesseling, Gerti (1985). Histoire politique du Sénégal, Institutions, droit et société. Paris: Karthala.

Irvine, Judith (2019) Minerva's orthography. Social Dynamics 45 (1): 26-52.

Juffermans, Kasper (2015). Local languaging, literacy and multilingualism in a West African society. Bristol: Multilingual Matters.

Keita, Abdoulaye. (2013). De l'alphabétisation à la littérature, la prise de parole didactique par des écrivaines wolof. Journal des Africanistes 83 (1): 156-179.

Lexander, Kristin V. \& Daniel Alcón López (forthcoming). Digital Language and New Configurations of Multilingualism: language use in a Senegal-based discussion forum. In Friederike Lüpke (ed.) Oxford Guide to the World's Languages: Atlantic. Oxford: Oxford University Press.

Lexander, Kristin V. \& Jannis Androutspoulos (2019). Working with mediagrams: a methodology for collaborative research on mediational repertoires in multilingual families, Journal of Multilingual and 
Multicultural Development, online first.

Lexander, Kristin V. (2011a). Pratiques plurilingues de l'écrit électronique : alternances codiques et choix de langue dans les SMS, les courriels et les conversations de la messagerie instantanée des étudiants de Dakar, Sénégal. Unpublished PhD thesis, University of Oslo.

Lexander, Kristin V. (2011b). Texting and African languages literacy. New Media and Society 13 (3): 427-443.

Lexander, Kristin V. (2012). Multilingual Texting in Senegal - A model for the study of mixed-langauge SMS. In Mark Sebba, Shahrzad Mahootian, \& Carla Jonsson (eds.), Language Mixing and CodeSwitching in Writing. Approaches to Mixed-language Written Discourse, 146-169. London: Routledge.

Lüpke, Friederike (2018). Escaping the tyranny of writing: West African regimes of writing as a model for multilingual literacy. In Constanze Weth \& Kasper Juffermans (eds.) The tyranny of writing revisited, 129-147. London: Bloomsbury.

Lüpke, Friederike (forthcoming). The writing's on the wall: Spaces for language-independent and language-based literacies. International Journal of Multilingualism 17(3).

Lüpke, Friederike \& Sokhna Bao-Diop (2014). Beneath the surface? Contemporary ajami writing in West Africa exemplified through Wolofal. In Kasper Juffermans, Yonas Mesfun Asfaha \& Ashraf Abdulhay (eds.), African literacies: Ideologies, scripts, education, 88-117. Newcastle upon Tyne: Cambridge Scholars Publishing.

Lüpke, Friederike \& Anne Storch (2013). Repertoires and choices in African languages. Berlin: de Gruyter Mouton.

Mbodj, Chérif (2002). Orthographe commune et legislations nationales. Une experience d'harmonisation de l’orthographe du wolof entre le Sénégal et la Mauritanie. In Kwesi Kwaa Prah (ed.) Writing African. The Harmonisation of orthographic conventions in African languages. CASAS: Cape Town. 
Mbodj-Pouye, Aïssatou \& Cécile van den Avenne (2007) "C'est bambara et français mélangés" Analyser des écrits plurilingues à partir du cas de cahiers villageois receuillis au Mali, Langage et Société, 120: 99-127.

Mbodj-Pouye, Aïssatou \& Cécile van den Avenne (2012). Vernacular Literacy Practices in Present-day Mali: Combining Ethnography and Textual Analysis to Understand Multilingual Texts. In Mark Sebba, Shahrzad Mahootian, and Carla Jonsson (eds.) Language Mixing and Code-Switching in Writing. Approaches to Mixed-Language Written Discourse, 170-191. London: Routledge.

Mc Laughlin, Fiona (2001). Dakar Wolof and the Configuration of an Urban Identity, Journal of African Cultural Studies 14 (2): 153-168.

Mc Laughlin, Fiona (2008a). Senegal: The Emergence of a National Lingua Franca. In Andrew Simpson (ed.), Language \& National Identity in Africa, 79-97. Oxford: Oxford University Press.

Mc Laughlin, Fiona (2008b). On the Origins of Urban Wolof: evidence from Louis Descemet's 1864 Phrase Book. Language in Society 37 (5): 713-735.

Mc Laughlin, Fiona (2014). Senegalese digital repertoires in superdiversity. A case study from Seneweb. In Discourse, Context and Media 4 (4): 29-37.

Mc Laughlin, Fiona (2015). Linguistic Warscapes of Northern Mali, Linguistic Landscape 1(3): 213-242.

Prinz, Manfred (1996). L'alphabétisation au Sénégal. Paris: I'Harmattan

Sebba, Mark (2007). Spelling and Society. London: Routledge.

Senghor, Léopold Sedar (1964). Le problème culturel en AOF, in Liberté I Négritude et humanisme, 1121. Paris: Seuil (article first published 1937).

Swigart, Leigh (1992). Two Codes or One? The insider's view and the description of codeswitching in Dakar, Journal of Multilingual and Multicultural Development 13 (1,2): 83-102.

Unesco (2020). Data for the Sustainable Development Goals.

http://uis.unesco.org/country/SN (accessed March 2020) 
Van den Avenne, Cécile (2012). Le petit manuel français-bambara à époque coloniale, entre description et appropriation pratique, Canadian Journal of African Studies / Revue canadienne des études africaines, 46 (2): 251-270.

\section{Acknowledgements}

This work was in part supported by the Research Council of Norway through its Centres of Excellence funding scheme, project number 223265. Thanks to Zaal Mbaye for help with translations from Wolof, Samba Diop, and two anonymous reviewers for valuable comments. 